\title{
Bacteremia After Prophylaxis
}

\author{
II \\ BY MAX B. WINSLOW,* D.D.s. AND SAMUEL H. MILLSTONE, $\dagger$ B.s., D.D.s., \\ DETROIT, MICHIGAN
}

$\mathrm{M}$ $\mathrm{UCH}$ investigative work has established that transient bacteremias are often caused by routine prophylaxis, removal of teeth and other oral procedures which cause bleeding. ${ }^{1-29,34,35}$ Bacteremias thus produced are of short duration and are not clinically significant in most instances. However, in individuals who have a background of acute rheumatic fever, rheumatic heart disease or other valvular heart disease, bacteremias, however transient, are potentially dangerous. $^{1,2,7,8,9,13,23,35}$ This should be taken into account when any periodontal or oral surgical procedure is contemplated.

Rheumatic heart disease is a complication of acute rheumatic fever and is the most common cause of organic heart disease in persons under the age of forty. ${ }^{30}$ One of the severe complications of rheumatic heart disease is subacute bacterial endocarditis. ${ }^{30,38}$ Before the advent of antibiotics this was almost always fatal. The majority of individuals thus affected now recover, but usually only after prolonged illness.

Approximately 20 per cent of cases of subacute bacterial endocarditis develop within several weeks after dental procedures. ${ }^{30,31}$ This occurs because of the relative frequency of transient bacteremias after prophylaxis, treatment of periodontal disease and other procedures which cause

From the Dental Division-Sinai Hospital, Detroit. This investigation supported by a grant from the research funds of Sinai Hospital.

*Attending Dentist and Chief, Section of Periodontics, Sinai Hospital, Detroit.

Visiting Lecturer, Postgraduate Periodontics School of Dentistry, University of Michigan.

$\dagger$ Associate Attending Dentist, Sinai Hospital, Detroit. bleeding. In individuals affected with heart disease bacteria may localize and multiply on deformed or damaged heart valves, resulting in further damage to already involved structures.

Prophylactic use of antibiotics has become standard practice in order to minimize the effects of bacteremias. The use of antibiotics for this purpose and many others has resulted in resistant strains of bacteria, anaphylactoid reactions and deaths, even in patients who have taken the drugs on numerous occasions without undesirable side effects. ${ }^{37}$ There are instances when this prophylactic use of antibiotics is overlooked because of failure to establish its need. Antibiotics have been administered topically, ${ }^{36}$ and have been effective in preventing transient bacteremias. Topical use, however, has been shown to cause sensitization and bacterial resistance much more frequently than oral or parenteral administration. Stomatitis venenata is another undesirable side effect of topical use.

A previous study has demonstrated a significant incidence of transient bacteremias following subgingival scaling. ${ }^{35}$

The present study was undertaken to determine whether the use of local germicidal drugs would prevent or significantly reduce the incidence of bacteremias in such cases. The drug selected was iodine lotion, which consists of:

phenol $5 \%-1$ part tincture of aconite- 2 parts

(by volume) tincture of iodine $31 / 2 \%$ 3 parts

$$
\text { glycerin-4 parts }
$$

The selection of iodine lotion was made for several reasons. This is a drug used for a long period of time on an empirical basis

Page 23/371 
during scaling and curetting procedures and is part of the armamentarium used in many dental offices. Iodine used alone would pose the possibility of burns. Iodine lotion seemed to be a combination which would exert a destructive effect on the bacterial content of periodontal pockets without undue reaction on the part of the tissues involved.

The pharmacology of the ingredients of iodine lotion is as follows:

phenol 5\%-antiseptic, disinfectant, germicide, anesthetic

tincture of aconite-anodyne, analgesic tincture of iodine $31 / 2 \%$-antiseptic, germicide

glycerin-demulcent, solvent

Since the previous study has shown that the incidence of bacteremia following subgingival scaling in the presence of gingivitis was not statistically significant, ${ }^{35}$ the investigation being reported was limited to cases exhibiting signs and symptoms of periodontitis. As in the previous study patients were selected and divided into two groups, periodontitis grade I and periodontitis grade II. The selection and classification was determined on the basis of the following criteria: abnormal changes in color, form, density and attachment of gingival tissues; ${ }^{32}$ discharge of serum or pus, hemorrhage, discomfort or pain, hypermobility of teeth and/or loss of alveolar bone and process. When these changes included the presence of periodontal pockets cases were diagnosed as periodontitis and were graded I or II according to the following changes: 1 . clinical hypermobility of grade I or more, ${ }^{39}$ 2. periodontal pockets of more than $3 \mathrm{~m} . \mathrm{m}$. of depth, 3. bifurcation and/or trifurcation involvements, and 4. loss of alveolar bone and process. The occurrence of at least two of these criteria, with pocket formation, indicated periodontitis grade II, whereas a less severe condition indicated periodontitis grade I.

The experimental procedure employed followed that of the previous study, ${ }^{35} \mathrm{ex}$ cept for the use of iodine lotion in the involved areas before scaling and curetting procedures. After thorough preparation of skin, a 10 c.c. sample of blood was drawn from the patient's anticubital vein both before and after the dental procedure. The blood was cultured on tryptase phosphate broth aerobically and anaerobically and subcultured at intervals of 48 hours, 72 hours and two weeks before a result was issued. The dental procedure consisted of routine calculus removal, curettement of crevicular epithelium and root planing. Before the procedure, the area used was isolated by cotton rolls and iodine lotion was instilled into the periodontal pockets by means of a blunt-tipped needle. The drug was allowed to remain for 5 minutes, after which the scaling and other procedures were performed for exactly two minutes and the second sample taken immediately on completion of the procedure. It was decided to limit the procedure to two minutes ${ }^{6}$ because bacteremias are of ten of short duration and it was felt that a longer period of time might result in missing positive findings. ${ }^{33}$

32 cases consisting of 13 cases of periodontitis grade I and 19 cases of periodontitis grade II were done in this manner. In sharp contrast to the findings in the first study no growth was obtained in any case.

\begin{tabular}{lccc}
\hline \multicolumn{1}{c}{ Group } & No. cases & $\begin{array}{c}\text { Pre- } \\
\text { treatment }\end{array}$ & $\begin{array}{c}\text { Post } \\
\text { treatment }\end{array}$ \\
\hline $\begin{array}{l}\text { Periodontitis } \\
\text { Grade I }\end{array}$ & 13 & 0 & 0 \\
\hline $\begin{array}{l}\text { Periodontitis } \\
\text { Grade II }\end{array}$ & 19 & 0 & 0 \\
\hline
\end{tabular}

Without the use of iodine lotion the incidence of bacteremia following scaling procedures was $22 \%$ in periodontitis grade I and $42 \%$ in periodontitis grade II. The predominant organisms recovered in the first study were Strep. viridans and staph. aureus. ${ }^{35}$ It should be noted that positive findings were obtained in the pre-treatment samples in 5 cases in the first study, and none in the second. This is probably accounted for by the fact that in the second 
study a closed bottle method was used in drawing blood and reduced the possibility of contamination. There is also the possibility that bacteria were present in the peripheral blood at the time the first sample was obtained.

A study by Bervell ${ }^{40}$ recently reported seems to substantiate the findings of this investigation. His work consisted of the use of an iodine resin varnish in healthy gingival crevices. No bacterial growth was obtained in 60 cases as compared with 57 positive findings without the application of iodine.

The statistical results of the two studies, Bacteremia after Prophylaxis I and II, support the conclusion that where periodontitis exists there is an increased risk of bacteremia as a result of dental procedures. The importance of careful history taking to determine the presence or past occurrence of rheumatic fever, rheumatic heart disease or other valvular heart disease is pointed out. In individuals reporting such a background, aseptic precautions are important. This study indicates that the topical use of germicidal drugs is of value in eliminating or perceptibly reducing the incidence of bacteremias following scaling and curetting procedures. The routine use of such drugs appears to be of value. Further work would be helpful in establishing whether topical use of such drugs can be depended upon to eliminate the production of bacteremias following scaling and surgical procedures. Until this has been demonstrated to be entirely dependable, prophylactic use of antibiotics should not be abandoned. The topical use of iodine lotion routinely seems to be of value in all situations. Its use in conjunction with antibiotic therapy where there is a concern about the effects of transient bacteremias is also indicated.

19457 Livernois Avenue Detroit, Michigan

\section{REFERENCES}

1. Northrop, P. M., and Crowley, Mary C. Prophylactic use of sulfathiazole in transient bacteremia following the extraction of teeth. A preliminary report. J. Oral Surg. 1:19 Jan. 1943.

2. Northrop, P. M. Penicillin therapy in oral surgery. J. Oral Surg. 7:39 Jan. 1949.

3. Abrahamson, L. Subacute bacterial endocarditis following removal of septic foci. Brit. M. J. 2:28 July 4, 1931.

4. Vanderhoof, D., and Davis, D. Subacute bacterial endocarditis following extraction of teeth. Virginia M. Monthly 60:151 June 1938.

5. Craig, Philip. Endocarditis and its dental interrelations. Ann. Den. 5:100 June 1938.

6. Burket, Lester W., and Burn, Caspar G. Bacteremias following dental extraction: demonstration of source of bacteria by means of non-pathogen. J. D. Res. 16:521 Dec. 1937.

7. Hopkins, J. A. Streptococcus viridans? bacteremia following extraction of teeth. J.A.D.A. 26: 2002 Dec. 1939.

8. Bender I. B., and Pressman R. S. Factors in dental bacteremia. J.A.D.A. 32:836 July 1945 .

9. Lazansky, J. P., Robinson, Leonard, and Rodofsky, Lillian. Factors influencing the incidence of bacteremias following surgical procedures in the oral cavity. J. D. Res. 28:533 Dec. 1949.

10. Barnfield, W. F. Subacute bacterial endocar- ditis and dental procedures. Am. J. Orthodont. \& Oral Surg. 31:55 Feb. 1945.

11. Faillo P. S. Blood findings on twenty patients before and after extraction of teeth. J. D. Res. 21:19 Feb. 1942.

12. Elliott, S. D. Bacteremia and oral sepsis. Proc. Roy. Soc. Med. 32:747 May 1939.

13. Pressman R. S., and Bender, I. B. Dental extractions and their relationship to subacute bacterial endocarditis. J. Albert Einstein Medical Center, Feb. 1953.

14. Fish, Wilfred E., and MacLean, I. The distribution of oral streptococci in the tissues. Brit. D. J. 61:336 Sept. 1936 .

15. Ray, H. G., and Orban, Balint. Deep necrotic foci in the gingiva. J. Periodont. 19:91 July 1948.

16. Murray M., and Moosnick, F. Incidence of bacteremia in patients with dental disease. J. Lab. and Clinic. Med. 26:801 Feb. 1941.

17. Richards, J. H. Bacteremia following irritation of foci of infection. J.A.M.A. 99:1496 Oct. 29, 1932.

18. Round Harold, Kirkpatrick, H. J. R., and Hails, C. G. Further investigation on bacterial infections of the mouth. Proc. Roy. Soc. Med. 29:1552 Oct. 1936.

19. Sand, R. A. Periodontal sepsis in relation to systemic disease. J.A.D.A. 28:710 May 1941 . 
20. Burket, Lester W. Oral Medicine: diagnosis, treatment. Philadelphia, J. B. Lippincott Co., 1946, p. 532 .

21. Miller, S. C. Textbook of periodontia. Philadelphia, Blakiston Co., 1950, p. 685.

22. Okell, C. C., and Elliott, S. D. Bacteremia and oral sepsis with special reference to the etiology of subacute endocarditis. Lancet 2:869 Oct. 19, 1935 .

23. Mitchell, David F., and Helman, Edith Z Role of periodontal foci of infection in systemic disease: an evaluation of the literature. J.A.D.A. 46:32 Jan. 1953.

24. Easlick, Kenneth A., and others. An evaluation of the effect of dental foci of infection on health. J.A.D.A. 42:609 June 1951.

25. Kraus F. W., and others. Classification of nonhemolytic streptococci recovered from bacteremia of dental origin. J. D. Res. 32:613 Oct. 1953 .

26. Massler, Maury and McDonald, J. B. Occurrence of beta hemolytic streptococci on the gingiva of normal young adults. J. D. Res. 29:43 Feb. 1950.

27. Amies, A. B. P. Clinical aspects of oral bacteriology. Austral. J. Den. 49:143 Sept. 1945.

28. Stones, H. H. Oral and dental diseases. Baltimore, Williams \& Wilkins 1948, ch. 33.

29. Glickman, Irving. Clinical periodontology. Philadelphia, W. B. Saunders Co., 1953, p. 477.

30. Comroe, B. I., Collins, L. H., Crane, M. P. Internal medicine in dental practice. Philadelphia, Lea \& Febiger, 1954, p. 512.
31. Kelson, S. R., and White, P. D. Notes on 250 cases of subacute bacterial (streptococcal) endocarditis studied and treated between 1927 and 1939 Ann. Int. Med. Jan. 1945.

32. Goldman, H. M. Periodontia. St. Louis, C. V. Mosby Co., 1953.

33. Crowley, Mary C. Personal communication.

34. Vargas B., and others. Effects of certain factors on bacteremias resulting from gingival resection. J. Periodont. 30:196 July 1959.

35. Winslow, Max B., and Kobernick, Sidney D. Bacteremia after prophylaxis. J.A.D.A. 83:70 July 1960 .

36. Diener, J., Schwartz, S. M., Shelanski, M., Steinberg, G. Bacteremia and oral sepsis with partic ular reference to the possible reduction of systemic disease. J. of Periodont. 44:236 Vol. 35, No. 3 .

37. Welch, H., Lewis, C. N., Weinstein, H. I., and Boeckman, B. B. Severe reactions to antibiotics, a nationwide survey. Antibiotic Med. 4:800, 1957.

38. Millard, H. D., and Tupper, C. J. Subacute bacterial endocarditis: a clinical study. J. Oral Surg., Anesth. and Hosp. D. Serv., Vol. 18, May 1960.

39. Ramfjord, S. P. Indices for Prevalence and Incidence of Periodontal Disease. J. Perio. Vol. 30, 51-59, January 1959.

40. Bervell, S. F. A. The Bacteriology of the Physiological Gingival Pockets. Acta. Odont. Scand. 22:167-183 June 1964 .

\section{WALTER REED DENTAL COURSES FOR 1965-1966 ANNOUNCED}

The U.S. Army Institute of Dental Research at Walter Reed Army Medical Center will offer seven postgraduate short courses during the 1965-66 academic year. Scheduled for this Fall are: "Trends in Dental Laboratory Activities" (27 Sept.-1 Oct.); "Preventive Dentistry" (25-29 Oct.); "Prosthodontics" (6-10 Dec.). Courses scheduled for 1966 are: "Oral Surgery" (10-14 Jan.); "Periodontics" (14-18 Feb.); "Advanced Pathology of the Oral Regions" (7-11 Mar.); and "Oral Diagnosis and Therapeutics" (2-6 May).

Attendance is open to Dental Corps Officers of the Federal Services on active duty, Reserve and National Guard Officers not on active duty, and qualified civilians. Officers on active duty must have at least six months remaining to serve in order to be considered for "in-service" courses.

For further details write to: Director, U.S. Army Institute of Dental Research, Walter Reed Army Medical Center, Washington, D.C. 20012.

\section{TEMPLE UNIVERSITY SCHOOL OF DENTISTRY}

Postgraduate Department, Temple University School of Dentistry offers a 4 day course in "Advanced Surgical Techniques in Periodontal Therapy," given by Dr. Saul Schluger and Dr. Jack Alloy. Dates: March 29 thru April 1, 1966. Tuition: $\$ 200.00$. For further information write to: Postgraduate Department, Temple University School of Dentistry, 3223 N. Broad Street, Philadelphia, Pa. 19140. 